\title{
Soft drink consumption of Grade 4 and Grade 7 learners in the Wynberg area, City of Cape Town, South Africa and the factors influencing the consumption
}

\author{
Hannelise Louwrens, Irma Venter ${ }^{*}$ Caralyn Otty
}

\section{OPSOMMING}

Die afgelope paar jaar was daar 'n skerp toename in die inname van gaskoeldrank en ' $n$ afname in die inname van melk en vrugtesap onder kinders. Dit is 'n kommerwekkende tendens, aangesien dit vele voedingsnadele vir kinders inhou. Die gereelde hoë suikerinname deur gaskoeldrankgebruik lei tot tandbederf en gewigstoename. Die gevolglike laer inname van voedingsryke drankies, soos melk en vrugtesap, belemmer ook die optimale inname van minerale (veral kalsium) en vitamiene. Daar is verskeie faktore wat daartoe bydra dat kinders gaskoeldrank verkies. Demografiese faktore soos geslag, ouderdom, ras, sosio-ekonomiese status en ook die woongebied van 'n kind kan aanleiding tot die inname van gaskoeldrank gee. In skoolverband is dit faktore soos die beskikbaarheid van gaskoeldrank in die snoepwinkel en die invloed van vriende wat kinders aanmoedig om gaskoeldrank te drink. Buite skoolverband word kinders aan advertensies wat gaskoeldrank bemark, blootgestel. Kinders kies ook gaskoeldrank bo gesonder drankies saam met wegneemetes. In die ouerhuis is die inname van gaskoeldrank deur die ouers self, die beskikbaarheid daarvan in die huishouding, ouers wat nie kinders se inname daarvan beperk nie en ook ouers met 'n laer opvoedingsvlak bydraende faktore tot gaskoeldrankinname onder kinders. Produkeienskappe soos die smaak, die verpakkingsgroottes en die prys is verdere faktore wat gaskoeldrankinname onder kinders aanmoedig.

Om die gaskoeldrankinname van leerders van twee verskillende ouderdomsgroepe en die faktore wat die inname daarvan beïnvloed na te gaan, is twee staatsskole in die Wynberg-omgewing (Stad Kaapstad) genader. Wynberg is ' $n$ gebied in ' $n$ middel tot laer sosio-ekonomiese klas waarvan die inwoners grotendeels die kleurling-bevolkingsgroep verteenwoordig. Die 179 kinders $(71,2 \%$ van dié wat vir deelname genader is) wat vrywillig deelgeneem het, bestaan uit 80 graad 4-leerders (42 meisies en 38 seuns) en 99 graad 7-leerders ( 55 meisies en 44 seuns). Die graad 4-leerders was tussen nege en tien jaar oud, terwyl die meeste graad 7-leerders ouer as twaalf jaar was. Goedkeuring vir die uitvoering van die studie is vooraf van die Navorsingskomitee van die Fakulteit Toegepaste Wetenskappe, Kaapse Skiereiland Universiteit van Tegnologie, en by albei skole se skoolhoofde verkry. Die deelnemers het 'n voorafgetoetste, selfgeadministreerde vraelys in die teenwoordigheid van die klasonderwyser en een van die navorsers voltooi.
Die meeste leerders $(93,3 \%)$ het aangedui dat hulle gewoonlik gaskoeldrank drink. Die gereelde gemiddelde gaskoeldrankinname per leerder per dag was $783 \mathrm{ml} \pm 510$ (nie-gebruikers uitgesluit), wat hoog is vergeleke met die uitslag in sommige ander studies. Leerders het meestal die $340 \mathrm{ml}$ - of die groter $500 \mathrm{ml}$-hoeveelhede $(39,5 \%$ en $40,1 \%$ onderskeidelik) gedrink, terwyl slegs $20,4 \%$ die kleiner 200 ml-hoeveelheid gedrink het. Graad 7leerders se gaskoeldrankinname was nie veel meer as dié van die graad 4-leerders nie, hoewel die graad 7-leerders groter hoeveelhede $(500 \mathrm{ml})$ ingeneem het en dit ook oor die algemeen meer gewild onder hulle was as onder die graad 4-leerders. Seuns se daaglikse gaskoeldrankinname was effens hoër as dié van die meisies omdat 'n groter persentasie van die seuns meer as drie porsies per dag ingeneem het. Gaskoeldrank is ook meer gewild onder seuns as meisies. Die hoofredes aangevoer vir die gaskoeldrankinname was dat dit die leerders se gunsteling-drankie is $(38,3 \%)$ en die smaak $(28,1 \%)$. Gaskoeldrank was ook deur die leerders aangedui as die drankie wat die meeste gedrink word $(63,5 \%)$, die drankie wat die meeste by die snoepwinkel gekoop word $(64,1 \%)$, en die gunsteling-drankie tydens restaurantbesoeke of saam met wegneemetes $(64,7 \%)$. Advertensies het ook die meeste $(80 \%)$ leerders beïnvloed om gaskoeldrank aan te koop.

Faktore buiten die produkeienskappe, soos die faktore binne die huishouding, binne die skool en buite die skool wat in die studie gevind is om die inname van gaskoeldrank te beïnvloed, moet op só ' $n$ manier beheer word dat kinders voortdurend daarvan bewus is om eerder meer voedingsryke drankies te drink as gaskoeldrank, wat op die lange duur gesondheidsnadele inhou. Drankies soos melk, jogurtdrankies, vrugtesappe of water en selfs dieetof onversoete (gas)koeldrank moet eerder aanbeveel of voorgesit word.

- Ms Hannelise Louwrens

Department of Agricultural and Food Sciences

Faculty of Applied Sciences

Cape Peninsula University of Technology

- Ms Irma Venter

Department of Agricultural and Food Sciences

Faculty of Applied Sciences

Cape Peninsula University of Technology

Tel: $+27(0) 214603428$

Email: Venterl@cput.ac.za

Soft drink consumption of Grade 4 and Grade 7 learners in the Wynberg area, City of Cape Town, 
* Corresponding author

- Ms Caralyn Otty

Department of Agricultural and Food Sciences

Faculty of Applied Sciences

Cape Peninsula University of Technology

ACKNOWLEDGEMENTS: The authors thank the headmasters of the two participating schools for their willingness to participate in the study and making the time available for the learners to complete the questionnaire, the parents/guardians for providing consent for their child's participation, and Mr F Rautenbach of the institution for the statistical analysis of the data.

\section{INTRODUCTION AND LITERATURE BACK- GROUND}

Soft drinks are non-alcoholic carbonated or noncarbonated beverages with sweeteners and flavourings as ingredients (Popkin et al, 2006). Sugar is a major ingredient (Jacobson, 2005:3). High soft drink consumption among children contributes to a decline in their milk and fruit juice consumption. This is a concern as some of the nutrients found in milk and fruit juice could become deficient in the child's diet (Harnack et al, 1999). Dietary quality and quantity of energy intake are the two main nutritional concerns when considering children's soft drink consumption (French et al, 2003) as soft drinks can be labelled 'empty calories' (Johnston et al, 2007). According to Whitney and Rolfes (1996:134), the nutrient composition of a $420 \mathrm{~kJ}$ serving of soft drink is $26 \mathrm{~g}$ carbohydrate, $6 \mathrm{mg}$ calcium and traces of iron. The current trend to fortify soft drinks with nutrients is questioned by nutritionists (Jacobson, 2005:22).

One of the major nutritional problems associated with soft drink consumption during childhood is the preference for soft drinks over milk, which has a negative effect on calcium intake, as milk is a rich source of this nutrient. Calcium is very important during the developing years, as it plays a role in bone formation and maintenance and the prevention of osteoporosis. Soft drink consumption itself may have negative nutritional consequences (Bowman, 2002). The phosphoric and carbonic acid content of carbonated soft drinks stimulate urinary excretion of calcium that may lead to bone loss (Mahmoud, 2009). The lack of milk in the diet also causes inadequate intake of other essential nutrients such as vitamin A, phosphorus, folate and magnesium (Bowman, 2002). Soft drinks furthermore contain caffeine, which also causes calcium excretion. Caffeine is mildly addictive and this could contribute to soft drink popularity. The amount of caffeine in even one or two cans of caffeinated soft drink can have a negative effect on a child's behaviour by affecting their mood, performance and ability to sleep (Jacobson, 2005:16).

A diet high in added sugars is suggested to dilute micronutrient intake. The low micronutrient content of soft drinks may explain the negative association found between the intake of added sugars and low micronutrient intake. A study on Norwegian children and adolescents found that soft drinks contributed on average $40 \%$ of the added sugar intake (Overby et al, 2003). A United States (US) study conducted to assess the relationship between beverage choices and nutrient intakes among children and adolescents, indicated that soft drinks were negatively associated with achieving adequate intake of calcium in children younger than twelve years, magnesium in children aged six years and older and vitamin $A$ in all ages (Ballew et al, 2000). The results from the National Food Consumption Survey (NFCS) in South Africa (SA) indicated that micronutrient intake (specifically vitamins $A, C, E$ and $B$, as well as iron, calcium and zinc) of many children in all age groups were inadequate. A significant inverse relation was found between sugar and thiamine, iron and zinc intake 
(Labadarios et al, 2005).

The American Academy of Pediatrics made recommendations to encourage a shift towards more nutritive beverages. This was based on data from a national survey of beverage consumption of children and adolescents. The data indicated that at the age of five years, soft drink consumption exceeded that of $100 \%$ fruit juice, and by the age of 13 , exceeded that of milk (Rampersaud et al., 2003). The percentage of children in SA needing treatment for dental caries ranges from 45 to $60 \%$ (Van Wyk \& Van Wyk, 2004). Based on these statistics, Steyn et al (2002) recommended, among other dietary factors, a lower intake of soft drinks.

St-Onge et al (2003) reported that $16 \%$ of US children aged six to eleven years are overweight and $14,3 \%$ are at risk of becoming overweight. The increase in soft drink and fast food consumption explains the rise in childhood obesity in this population group. Soft drink consumers take in $790 \mathrm{~kJ}$ per day more than non-consumers. A study in California on schoolchildren found that the time spent in front of the television, and the number of soft drinks they consumed per day, was associated with both their body mass index and their body fat as a percentage of their body weight (Giammattei et al, 2003). According to a 2005 report (Jacobson, 2005:iv) American teenagers obtained $13 \%$ of their energy intake from soft drinks. In the twelve- to nineteen-year-age group, American boys consumed on average approximately 15 teaspoons of sugar, and American girls ten teaspoons of sugar, through their soft drink consumption. Studies have proved that soft drink consumption is linked to obesity in children, which increases the risk for type 2 diabetes, heart attacks, strokes and cancer in later life (Jacobson, 2005:iv). Summarised dietary data indicated that the soft drink consumption of South African children contributed $6 \%$ towards their daily energy and macronutrient intake. The data also indicated that the average serving size of soft drinks consumed by $5,3 \%$ of South African children aged one to nine years was $301,6 \mathrm{~g}$ per day (Steyn et al, 2006). A total of $10,5 \%$ of children in urban areas consumed an average serving size of $348,1 \mathrm{~g}$ soft drink per day ( $\mathrm{Nel} \&$ Steyn, 2002:91).

Several factors exert an influence on a child's choice of both the type of beverages and the amount consumed (Grimm et al, 2004). A study by Grimm et al (2004), to determine the factors associated with soft drink consumption among school-aged children, found taste to be the strongest predictor. Parental influence also plays a role. Children whose parents consumed soft drinks regularly are prone to consume soft drinks on a regular basis. This may be due to such parents not restricting their children's intake, or the availability of soft drinks in the household. Children whose parents have lower levels of education furthermore consumed more soft drinks than those whose parents have higher levels of education (Cullen et al, 2002).

Although parental influence played an important role, environmental factors also contributed to children's beverage intake (Fried \& Nestle, 2002). Availability of larger single-serving package sizes, lower prices (Jacobson, 2005:3) and increased national trends towards eating out (French et al, 2003) were such contributing factors. The increased consumption of soft drinks has been linked to the larger container sizes provided by the soft drink industry (Jacobson, 2005:3).

Factors such as television viewing, peer influences and the availability of soft drinks at school were further environmental factors associated with soft drink consumption among children (Grimm et al, 2004). Half of the soft drinks consumed by American children are bought at school. American children from a low income background and those from rural schools specifically have high soft drink consumption at school, as well as an overall high consumption of these beverages (Fernandes, 2008). Soft drink companies market their products to children in and out of school. Examples of soft drink marketing in schools include sponsorships of sport events or logos on vending machines. Marketing outside the school occurs through the television, internet, magazines and consumption of soft drinks in films (Nestle, 2000).

Gender, age and race influence soft drink consumption of children (Forshee \& Storey, 2003). A study conducted to determine the different influences on soft drink consumption and choices by US youth (aged six to seventeen years) concluded that there was a larger soft drink consumption by boys than girls and a larger increase in consumption by boys than girls as their age increases (French et al, 2003). Another study indicated that in the United States of America (USA), $12 \%$ of preschool children consumed an average of nine ounces $(266,4 \mathrm{ml})$ of soft drinks per day compared to more than $30 \%$ of school-aged children consuming this amount per day. Data for this study was obtained through two one-day dietary recalls (Harnack et al, 1999). After the age of four years the consumption of beverages with added sweeteners increased (Rampersaud et al, 2003). With reference to race, the US Department of Agriculture (USDA) Continuing Survey of Food Intake by Individuals (CSFII) indicated that white US boys and girls consumed more soft drinks than both genders of AfricanAmericans of the same age group (Forshee \& Storey, 2003).

The objectives of this study were firstly to determine the consumption of soft drinks among learners, in particular that of younger and older children in schools located in a middle to lower socioeconomic urban area of the City of Cape Town and secondly to determine the factors that influence the consumption within the learner group.

\section{METHOD}

This descriptive survey conducted in 2005 used cluster sampling to obtain the learners for participation. The sample consisted of Grade 4 learners (nine and ten year olds) and Grade 7 learners (twelve and thirteen year olds) from two government schools in the Wynberg area. The household income per annum for 
$59,66 \%$ of the Wynberg population is below R76 801 (Strategic Development Information and GIS, 2001) and falls in the third quintile income per household distribution for 2005/2006 in SA (Statistics SA, 2005/2006). The demographic profile of the Wynberg population represents a middle to lower socioeconomic class.

Permission to conduct the survey was obtained from the Research Committee of the Faculty of Applied Sciences, Cape Peninsula University of Technology and from the headmasters of the two respective schools. A response rate of $71,2 \%$ was obtained, as 185 consent forms were returned positively, out of the 260 that were dispatched to the learners' parents and guardians. Six questionnaires were rejected as they were incomplete. The final sample group was 179 learners.

The data were collected by using a self-administered questionnaire which included multiple-choice questions regarding learner demographics $(n=2)$, beverage consumption and preferences $(n=12)$, reasons for soft drink consumption $(n=2)$ and beverages purchased with tuck shop money received $(n=2)$. The questionnaire content was evaluated by a dietician with post-graduate qualifications in nutrition to assure content validity, as recommended by Parmenter \& Wardle (2000). The questionnaire was given to both the headmasters for their consent. In the approval process, feedback was received from both the schools on simplifying question and response wording. This assured that all the questions were written at a basic comprehension level so that the learners could understand and answer with ease. The question responses ranged from two ( $n=2$ questions) up to eight ( $n=6$ questions). The responses were formulated similarly for a number of the questions (i.e. two questions with the same three response answers, three questions with the same three response answers, five questions with the same eight response answers and three questions with five similar response answers). The three remaining questions all had different response answers (one question each with respectively four, six and eight responses). Thereafter, the questionnaire was pilot tested with a small sample of learners representing $10 \%$ of the final number of the sample group $(n=22)$. This ensured face validity, as recommended by Neuman (2006:193). The only change made to the questionnaire was placing a block on the cover page for the learners to indicate the grade they were in. This enabled the researchers to identify the different grade groups' questionnaires. Assistance was provided to the learners during completion of the questionnaire by both the class teachers and one of the researchers. Questions and answer responses were read to the children and this ensured that the learners selected only one response per question. A singleadministration study was conducted, as the selected learner group was predominantly those aged nine to ten years and older. Evidence suggests that from the age of eight years, children can self-report their dietary intake as reliably as their parents (Livingstone \& Robson, 2000).
The data were analysed using both MS Excel spreadsheets and the STATISTICA data analysis software system version 7.1 (Statsoft Inc, 2005). Two questions respectively referring to the size or volume $(\mathrm{ml})$ consumed at a time and the number of soft drinks usually consumed in a day was used to calculate the usual daily soft drink consumption. A quantity of 200 $\mathrm{ml}$ was allocated to a small can or a small to medium glass, $340 \mathrm{ml}$ as the average amount of a large can $(330 \mathrm{ml})$ to large glass $(350 \mathrm{ml})$ (Langenhoven et al, 1991:ii) and $500 \mathrm{ml}$ to a bottle as referred to in the questionnaire. A small can, large can and bottle was indicated as the consumption quantities as these container sizes were known to the learners in the pilot study. A soft drink serving was taken as $340 \mathrm{ml}$ as the average of a large can and a large glass which approximates the serving size indicated by Storey et al (2004) of $355 \mathrm{~g}$. The Pearson chi-square test was used to determine either the association or difference between the response categories of the learner grades and genders and genders within the grades. The Mann-Whitney test was used to determine differences between the learner soft drink consumption as continuous data. A significance level of $5 \%(p<0,05)$ was used.

For an accurate comparison of soft drink consumption with other reported studies, non-alcoholic carbonated beverages containing sugar as sweetener were considered soft drinks and the amounts given in fluid ounces were converted to millilitres $(\mathrm{ml})$. One ounce in US terms is equal to $29,6 \mathrm{ml}$, and in the United Kingdom one ounce is equal to $28,4 \mathrm{ml}$.

Due to the single-administration design of the study, the internal consistency reliability (Struwig \& Stead, 2001:132) (measurement reliability across different specific indicators or equivalence reliability as described by Neuman, 2006:190) was determined based on five related questions in the questionnaire that measured the same general construct (i.e. beverage choices). The Cronbach's coefficient alpha for these items was 0.66 , indicating an acceptable reliability. This measurement may also provide evidence for convergent validity, as described by Neuman (2006:194), of the questionnaire. As a further measure of validity the group differences approach (Struwig \& Stead, 2001:141) was used to determine if the groups (four learner groups in the two participating schools) differed in their calculated usual daily soft drink consumption. One-way analysis of variance (one-way ANOVA) of the data indicated no consumption difference between the groups $(p=0,362)$. This analysis also provided evidence for representative reliability or measurement reliability across groups (Neuman, 2006:189).

\section{RESULTS AND DISCUSSION}

\section{Respondent demographics}

The gender and age distribution of the respondent group of 80 Grade 4 learners and 99 Grade 7 learners are indicated in Table 1. 
TABLE 1: DEMOGRAPHIC CHARACTERISTICS OF THE RESPONDENT SAMPLE (N = 179)

\begin{tabular}{|l|c|c|c|c|}
\hline \multicolumn{1}{|c|}{ Demographic characteristics } & \multicolumn{2}{c|}{ Grade 4 learners $\mathbf{n}=\mathbf{8 0})$} & \multicolumn{2}{c|}{ Grade 7 learners $(\mathbf{n}=\mathbf{9 9})$} \\
\hline Gender & $\%$ & $\mathrm{n}$ & $\%$ & $\mathrm{n}$ \\
\hline Girls & 52,5 & 42 & 55,5 & 55 \\
\hline Boys & 47,5 & 38 & 44,5 & 44 \\
\hline Age & & & & 0 \\
\hline$<9$ years & 1,2 & 1 & 0 & 0 \\
\hline 9 years & 12,5 & 10 & 0 & 0 \\
\hline 10 years & 65,0 & 52 & 0 & 1 \\
\hline 11 years & 17,5 & 14 & 1,0 & 43 \\
\hline 12 years & 3,7 & 3 & 43,4 & 55 \\
\hline 13 years and older & 0 & 0 & 55,6 & \\
\hline
\end{tabular}

\section{Learner soft drink consumption}

Average soft drink consumption The majority of the learners $(93,3 \%)$ indicated that they consumed soft drinks (Table 2). The usual amount of soft drinks consumed by the learner group (consumers and nonconsumers) averaged $730 \mathrm{ml}$ per day, and the usual amount consumed by the learners, excluding the nonconsumers, averaged $783 \mathrm{ml}$ per day. The usual soft drink consumption per day of the Grade 7 learners and the boys was calculated to be higher $(799 \mathrm{ml}$ and $850 \mathrm{ml}$ respectively) than that calculated for the Grade 4 learners and the girls $(763 \mathrm{ml}$ and $722 \mathrm{ml}$ respectively). The usual consumption of soft drinks was significantly different $(p<0,05)$ between the two genders and between the boys and the girls in Grade 4 , but not significantly different $(p>0,05)$ between the two grades and the boys and girls in Grade 7.

Harnack et al (1999), in reporting the USDA CSFII, indicated that $35,9 \%$ of school-aged children (six to twelve years) were non-consumers of soft drinks, $31,8 \%$ consumed between 0,1 to 8,9 ounces $(3 \mathrm{ml}$ to $263,4 \mathrm{ml}$ ) per day, while $32,3 \%$ consumed nine ounces $(266,4 \mathrm{ml})$ or more. In the older age group (13 to 18 years), only $17,5 \%$ of adolescents were nonconsumers and $32,2 \%$ consumed between 0,1 and
12,9 ounces $(3 \mathrm{ml}$ to $381,8 \mathrm{ml}$ ), 28,1\% between 13 and 25,9 ounces $(384,8 \mathrm{ml}$ to $766,6 \mathrm{ml})$, and $22,2 \%$ consumed 26 ounces $(769,6 \mathrm{ml})$ or more per day. The higher percentage of soft drink non-consumers found in this US study of comparable age than that recorded for the Wynberg learners could be attributed to the dietary intake methodology used in the former study to determine the soft drink consumption. The soft drink consumption was obtained through two one-day dietary recalls (Harnack et al, 1999), that represented the soft drink consumption of the previous day(s), and not a usual intake. Data from the USDA CSFII indicated that in the age group nine to eighteen years, $28,9 \%$ did not consume any soft drinks. The data were obtained using a multi-pass 24 hour dietary recall (Storey et al, 2004).

In a study at a middle school in Houston, Texas, the beverage intake of Grade 4, 5 and 6 learners was obtained through self-reported dietary records. The consumption of soft drinks increased the higher the grade groups, as the Grade 4 learners had an average intake of 5,2 ounces $(153,9 \mathrm{ml})$, the Grade 5 learners 6,7 ounces $(198,3 \mathrm{ml})$ and the Grade 6 learners 7,2 ounces $(213,1 \mathrm{ml})$ per day, calculated over three- to seven-day dietary records (Cullen et al, 2002). This consumption was less than that found for

TABLE 2: USUAL AMOUNT (ML) OF SOFT DRINKS CONSUMED BY THE LEARNERS PER DAY

\begin{tabular}{|c|c|c|c|c|c|c|c|c|c|}
\hline \multirow{4}{*}{$\begin{array}{l}\text { Descriptive } \\
\text { statistics }\end{array}$} & \multirow{4}{*}{$\begin{array}{l}\text { Total respondent } \\
\text { group }\end{array}$} & \multicolumn{2}{|c|}{ Grade } & \multicolumn{2}{|c|}{ Gender } & \multicolumn{4}{|c|}{ Gender within grades } \\
\hline & & \multirow{2}{*}{\begin{tabular}{|l|} 
Grade 4 \\
$(n=80)^{c}$ \\
\end{tabular}} & \multirow{2}{*}{$\begin{array}{l}\text { Grade } 7 \\
(n=99)^{d}\end{array}$} & \multirow{2}{*}{$\begin{array}{l}\text { All boys } \\
(n=82)^{e}\end{array}$} & \multirow{2}{*}{\begin{tabular}{|l} 
All girls \\
$(n=97)^{f}$
\end{tabular}} & \multicolumn{2}{|c|}{ Grade 4} & \multicolumn{2}{|c|}{ Grade 7} \\
\hline & & & & & & Boys & Girls & Boys & Girls \\
\hline & & & & & & $(n=38)^{9}$ & $(n=42)^{h}$ & $(n=44)^{i}$ & $(n=55) j$ \\
\hline \multicolumn{10}{|c|}{ Usual amount (ml) of soft drinks consumed by the total respondent group $(n=179)^{a}$} \\
\hline Mean \pm SD & $730 \pm 530$ & $725 \pm 500$ & $734 \pm 556$ & $819 \pm 552$ & $655 \pm 501$ & $892 \pm 530$ & $574 \pm 422$ & $755 \pm 569$ & $717 \pm 550$ \\
\hline Minimum & 0 & 0 & 0 & 0 & 0 & 200 & 0 & 0 & 0 \\
\hline Maximum & 2000 & 2000 & 2000 & 2000 & 2000 & 2000 & 1500 & 2000 & 2000 \\
\hline Median & 680 & 680 & 500 & 680 & 500 & 840 & 450 & 500 & 680 \\
\hline \multicolumn{10}{|c|}{ Usual amount (ml) of soft drinks consumed by the respondent group, excluding the non-consumers $(n=167)^{b}$} \\
\hline & & $(n=76)$ & $(n=91)$ & $(n=76)$ & $(n=88)$ & $(n=38)$ & $(n=38)$ & $(n=41)$ & $(n=50)$ \\
\hline Mean \pm SD & $783 \pm 510$ & $763 \pm 483$ & $799 \pm 533$ & $850 \pm 538$ & $722 \pm 478$ & $892 \pm 530$ & $634 \pm 397$ & $810 \pm 550$ & $789 \pm 525$ \\
\hline Minimum & 200 & 200 & 200 & 200 & 200 & 200 & 200 & 200 & 200 \\
\hline Maximum & 2000 & 2000 & 2000 & 2000 & 2000 & 2000 & 1500 & 2000 & 2000 \\
\hline Median & 680 & 680 & 680 & 680 & 680 & 840 & 590 & 500 & 680 \\
\hline
\end{tabular}

aef,agh Significant difference $(p<0,05)$ between variables

acd,ai, bcd,bef,bgh,bij No significant association/difference $(p>0,05)$ between variables

Soft drink consumption of Grade 4 and Grade 7 learners in the Wynberg area, City of Cape Town,

South Africa and the factors influencing the consumption 
TABLE 3: USUAL AVERAGE SERVINGS OF SOFT DRINKS CONSUMED BY THE LEARNERS PER DAY

\begin{tabular}{|c|c|c|c|c|c|c|c|c|c|c|c|c|c|c|c|c|c|c|}
\hline \multirow{4}{*}{ Servings a per day } & \multirow{4}{*}{\multicolumn{2}{|c|}{$\begin{array}{c}\text { Total respon- } \\
\text { dent group }(n= \\
167)\end{array}$}} & \multicolumn{4}{|c|}{ Grade } & \multicolumn{4}{|c|}{ Gender } & \multicolumn{8}{|c|}{ Gender within grades } \\
\hline & & & \multicolumn{2}{|c|}{ Grade 4} & \multicolumn{2}{|c|}{ Grade 7} & \multicolumn{2}{|c|}{ All boys } & \multicolumn{2}{|c|}{ All girls } & \multicolumn{4}{|c|}{ Grade 4} & \multicolumn{4}{|c|}{ Grade 7} \\
\hline & & & & & & & & & & & $\mathrm{Bo}$ & ys & & rls & & & & irls \\
\hline & & & \multicolumn{2}{|c|}{$(n=76)$} & \multicolumn{2}{|c|}{$(n=91)$} & \multicolumn{2}{|c|}{$(n=79)$} & \multicolumn{2}{|c|}{$(n=88)$} & \multicolumn{2}{|c|}{$(n=38)$} & \multicolumn{2}{|c|}{$(n=38)$} & \multicolumn{2}{|c|}{$(n=41)$} & \multicolumn{2}{|c|}{$(n=50)$} \\
\hline $\begin{array}{c}\text { Average servings per } \\
\text { day }\end{array}$ & \multicolumn{2}{|c|}{2,3} & \multicolumn{2}{|c|}{2,2} & \multicolumn{2}{|c|}{2,4} & \multicolumn{2}{|c|}{2,5} & \multicolumn{2}{|c|}{2,1} & \multicolumn{2}{|c|}{2,6} & \multicolumn{2}{|c|}{1,9} & \multicolumn{2}{|c|}{2,4} & \multicolumn{2}{|c|}{2,3} \\
\hline $\begin{array}{c}\text { Number of servings per } \\
\text { day }\end{array}$ & $\%$ & $\mathrm{n}$ & $\%$ & $\mathrm{n}$ & $\%$ & $\mathrm{n}$ & $\%$ & $\mathrm{n}$ & $\%$ & $\mathrm{n}$ & $\%$ & $\mathrm{n}$ & $\%$ & $\mathrm{n}$ & $\%$ & $\mathrm{n}$ & $\%$ & $\mathrm{n}$ \\
\hline Less than one & 26,3 & 44 & 27,6 & 21 & 25,3 & 23 & 21,5 & 17 & 30,7 & 27 & 23,7 & 9 & 31,6 & 12 & 19,5 & 8 & 30,0 & 15 \\
\hline Between one and two & 32,9 & 55 & 31,6 & 24 & 34,1 & 31 & 36,7 & 29 & 29,5 & 26 & 26,3 & 10 & 36,8 & 14 & 46,3 & 19 & 24,0 & 12 \\
\hline Between two and three & 22,8 & 38 & 23,7 & 18 & 22,0 & 20 & 19,0 & 15 & 26,1 & 23 & 26,3 & 10 & 21,1 & 8 & 12,2 & 5 & 30,0 & 15 \\
\hline More than three & 18,0 & 30 & 17,1 & 13 & 18,7 & 17 & 22,8 & 18 & 13,6 & 12 & 23,7 & 9 & 10,5 & 4 & 22,0 & 9 & 16,0 & 8 \\
\hline
\end{tabular}

aOne soft drink serving $=340 \mathrm{ml}$ taken as the average amount of a large can and a large glass which approximates the serving size indicated by Storey et al (2004) of $355 \mathrm{~g}$

this study, as the non-consumers of soft drinks were also included in the Houston learner group. Jacobson (2005:i) furthermore indicated that in 1999/2000, the average 13- to 18-year-old American boy consumed the equivalent of two 12-ounce $(355,2 \mathrm{ml})$ cans $(710,4$ $\mathrm{ml}$ ) of soft drink per day and the average American girl one and a third can $(473,6 \mathrm{ml})$ per day, with the amounts respectively increasing if the non-consumer data were eliminated to 32 ounces $(947,2 \mathrm{ml})$ and 23 ounces $(680,8 \mathrm{ml})$. These correspond with the amounts consumed in this study (Table 2).

Average number of servings consumed per day The average number of servings usually consumed by the respondent group was 2,3 servings per day (Table 3). Grade 4 girls consumed the least number of servings $(1,9)$, while Grade 4 boys consumed the highest number of servings $(2,6)$ per day. Overall, approximately one-quarter $(26,3 \%)$ of the learners usually consumed less than one serving, one-third $(32.9 \%)$ usually one to two servings and $18 \%$ usually more than three soft drink servings per day.

In the respondent group, most learners indicated that they usually consumed one or two soft drinks (38.3\% and $37.1 \%$ respectively) per day (Table 4 ). There was no significant associations or differences in the number of soft drinks usually consumed per day between the grades $(p>0,05)$, the genders $(p>0,05)$ and the genders within the grades $(p>0,05)$. Both the grades and the genders and both genders within each of the grades indicated that they usually consumed one or two soft drinks per day. Within Grade 4, 32,9\% of the learners usually consumed one soft drink and $43,4 \%$ two soft drinks per day, while in Grade $742,9 \%$ of the learners usually consumed one soft drink and $31,9 \%$ two soft drinks per day $(p>0,05)$. An equal percentage of the boys and girls usually consumed one soft drink per day (38\% and $38,6 \%$ respectively), while a near equal percentage also usually consumed two soft drinks per day (34,2\% and $39,8 \%$ respectively) ( $p$ $>0,05)$. In Grades 4 and 7 most of the boys and girls also usually consumed one $(28.9 \%$ and $46,3 \%$ respectively and $36,8 \%$ and $40 \%$ respectively) or two (44,7\% and $24,4 \%$ respectively and $42,1 \%$ and $38 \%$ respectively) soft drinks per day $(p>0,05)$.

Volume of soft drinks consumed at a time An equal number and most of the learners (40\%) usually consumed a large can or large glass $(340 \mathrm{ml})$ and the bottle amount $(500 \mathrm{ml})$ (Table 5$)$. There was no significant associations or differences in the size or volume of the soft drinks usually consumed at a time between the grades $(p>0,05)$ or the genders $(p>$ $0,05)$, but a significant difference between the genders within the grades $(p<0,05)$. Although more Grade 4 learners usually consumed $340 \mathrm{ml}(44,7 \%)$ rather than $500 \mathrm{ml}(31,6 \%)$, and more Grade 7 learners usually consumed $500 \mathrm{ml}(47,3 \%)$ rather than 340 $\mathrm{ml}(35,2 \%)$ the difference was not significant $(p>$ $0,05)$. The $340 \mathrm{ml}$ and the $500 \mathrm{ml}$ volumes was consumed by almost an equal percentage of boys $(44,3 \%$

TABLE 4: NUMBER OF SOFT DRINKS USUALLY CONSUMED BY THE LEARNERS PER DAY

\begin{tabular}{|c|c|c|c|c|c|c|c|c|c|c|c|c|c|c|c|c|c|c|}
\hline \multirow{4}{*}{$\begin{array}{c}\text { Number of soft } \\
\text { drinks }^{\mathrm{a}}\end{array}$} & \multirow{3}{*}{\multicolumn{2}{|c|}{$\begin{array}{c}\text { Total } \\
\text { respondent } \\
\text { group }(n=167)\end{array}$}} & \multicolumn{4}{|c|}{ Grade } & \multicolumn{4}{|c|}{ Gender } & \multicolumn{8}{|c|}{ Gender within grades } \\
\hline & & & \multirow{2}{*}{\multicolumn{2}{|c|}{$\begin{array}{l}\text { Grade } 4^{b} \\
(n=76)\end{array}$}} & \multirow{2}{*}{\multicolumn{2}{|c|}{$\begin{array}{l}\text { Grade } 7^{b} \\
(n=91)\end{array}$}} & \multirow{2}{*}{\multicolumn{2}{|c|}{$\begin{array}{c}\text { All } \\
\text { boys }^{c} \\
(n=79)\end{array}$}} & \multirow{2}{*}{\multicolumn{2}{|c|}{$\begin{array}{c}\text { All } \\
\text { girlsc } \\
(n=88)\end{array}$}} & \multicolumn{4}{|c|}{ Grade 4} & \multicolumn{4}{|c|}{ Grade 7} \\
\hline & & & & & & & & & & & \multicolumn{2}{|c|}{$\begin{array}{c}\text { Boys }^{d} \\
(n=38)\end{array}$} & \multicolumn{2}{|c|}{$\begin{array}{c}\text { Girls }^{d} \\
(n=38)\end{array}$} & \multicolumn{2}{|c|}{$\begin{array}{l}\text { Boys }^{d} \\
(n=41)\end{array}$} & \multicolumn{2}{|c|}{$\begin{array}{c}\text { Girls }^{d} \\
(n=50)\end{array}$} \\
\hline & $\%$ & $n$ & $\%$ & $\mathrm{n}$ & $\%$ & $\mathrm{n}$ & $\%$ & $n$ & $\%$ & $n$ & $\%$ & $\mathrm{n}$ & $\%$ & $n$ & $\%$ & $\mathrm{n}$ & $\%$ & $\mathrm{n}$ \\
\hline One & 38,3 & 64 & 32,9 & 25 & 42,9 & 39 & 38,0 & 30 & 38,6 & 34 & 28,9 & 11 & 36,8 & 14 & 46,3 & 19 & 40,0 & 20 \\
\hline Two & 37,1 & 62 & 43,4 & 33 & 31,9 & 29 & 34,2 & 27 & 39,8 & 35 & 44,7 & 17 & 42,1 & 16 & 24,4 & 10 & 38,0 & 19 \\
\hline Three & 10,2 & 17 & 10,5 & 8 & 9,9 & 9 & 7,6 & 6 & 12,5 & 11 & 7,9 & 3 & 13,2 & 5 & 7,3 & 3 & 12,0 & 6 \\
\hline More than three & 14,4 & 24 & 13,2 & 10 & 15,4 & 14 & 20,3 & 16 & 9,1 & 8 & 18,4 & 7 & 7,9 & 3 & 22,0 & 9 & 10,0 & 5 \\
\hline
\end{tabular}

ab,ac,ad No significant association/difference $(p>0,05)$ between variables as number of soft drinks usually consumed per day (a) and the grades (b); the genders (c); the genders within the grades (d) 
ISSN 0378-5254 Journal of Family Ecology and Consumer Sciences, Vol 38, 2010

TABLE 5: SIZE OR VOLUME OF SOFT DRINKS USUALLY CONSUMED BY THE LEARNERS AT A TIME

\begin{tabular}{|c|c|c|c|c|c|c|c|c|c|c|c|c|c|c|c|c|c|c|}
\hline \multirow{4}{*}{$\begin{array}{c}\text { Size or volume } \\
\text { of soft } \\
\text { drinks }\end{array}$} & \multirow{3}{*}{\multicolumn{2}{|c|}{$\begin{array}{c}\text { Total } \\
\text { respondent } \\
\text { group } \\
(n=167)\end{array}$}} & \multicolumn{4}{|c|}{ Grade } & \multicolumn{4}{|c|}{ Gender } & \multicolumn{8}{|c|}{ Gender within grades } \\
\hline & & & \multirow{2}{*}{\multicolumn{2}{|c|}{$\begin{array}{l}\text { Grade } 4^{b} \\
(n=76)\end{array}$}} & \multirow{2}{*}{\multicolumn{2}{|c|}{$\begin{array}{c}\text { Grade } 7 \mathrm{~b} \\
(n=91)\end{array}$}} & \multirow{2}{*}{\multicolumn{2}{|c|}{$\begin{array}{c}\text { All } \\
\text { boys } \\
(n=79)\end{array}$}} & \multirow{2}{*}{\multicolumn{2}{|c|}{$\begin{array}{c}\text { All } \\
\text { girlsc } \\
(n=88)\end{array}$}} & \multicolumn{4}{|c|}{ Grade 4} & \multicolumn{4}{|c|}{ Grade 7} \\
\hline & & & & & & & & & & & \multicolumn{2}{|c|}{$\begin{array}{l}\text { Boys }^{d} \\
(n=38)\end{array}$} & \multicolumn{2}{|c|}{$\begin{array}{l}\text { Girlse } \\
(n=38)\end{array}$} & \multicolumn{2}{|c|}{$\begin{array}{l}\text { Boys }^{f} \\
(n=41)\end{array}$} & \multicolumn{2}{|c|}{$\begin{array}{l}\text { Girlsg } \\
(n=50)\end{array}$} \\
\hline & $\%$ & $\bar{n}$ & $\%$ & $\bar{n}$ & $\%$ & $\mathrm{n}$ & $\%$ & $\mathrm{n}$ & $\%$ & $\bar{n}$ & $\%$ & $\bar{n}$ & $\%$ & $\mathrm{n}$ & $\%$ & $\mathrm{n}$ & $\%$ & $\bar{n}$ \\
\hline $\begin{array}{c}200 \mathrm{ml} \text { (small } \\
\text { can or small to } \\
\text { medium glass) }\end{array}$ & 20,4 & 34 & 23,7 & 18 & 17,6 & 16 & 10,1 & 8 & 29,5 & 26 & 7,9 & 3 & 39,5 & 15 & 12,2 & 5 & 22,0 & 11 \\
\hline $\begin{array}{c}340 \mathrm{ml} \text { (large can } \\
\text { or large glass) }\end{array}$ & 39,5 & 66 & 44,7 & 34 & 35,2 & 32 & 44,3 & 35 & 35,2 & 31 & 47,4 & 18 & 42,1 & 16 & 41,5 & 17 & 30,0 & 15 \\
\hline $500 \mathrm{ml}$ (bottle) & 40,1 & 67 & 31,6 & 24 & 47,3 & 43 & 45,6 & 36 & 35,2 & 31 & 44,7 & 17 & 18,4 & 7 & 46,3 & 19 & 48,0 & 24 \\
\hline
\end{tabular}

ab,ac,adf,afg No significant association/difference $(p>0,05)$ between variables as the size or volume of soft drinks usually consumed at a time (a) and the grades (b); the genders (c); the Grade 4 boys (d) and Grade 7 boys (f); the Grade 7 boys (f) and Grade 7 girls ( $g$ )

ade,aeg Significant difference $(p<0,05)$ between variables as the size or volume of soft drinks usually consumed as a time (a) and the Grade 4 boys (d) and Grade 4 girls (e); the Grade 4 girls (e) and Grade 7 girls (g)

and $45,6 \%$ respectively) and girls (35,2\% each) $(\mathrm{p}>$ $0,05)$. The difference within the size or volume of the soft drinks consumed between the Grade 4 girls and boys and the Grade 4 girls and Grade 7 girls was however significant $(p<0,05)$, with a smaller percentage of the Grade 4 girls $(18,4 \%)$ than the Grade 4 boys $(44,7 \%)$ and the Grade 7 girls $(48 \%)$ that consumed the larger $500 \mathrm{ml}$.

\section{Reasons for learner soft drink consumption}

More than one-third of the learner group $(38,3 \%)$ indicated that they consumed soft drinks because it was their favourite beverage (Table 6 ). The next reason provided by nearly one-third of the learners $(28,1 \%)$ was the taste. There was furthermore no significant associations or differences in the reasons provided by the learners for their soft drink consumption between the grades $(p>0,05)$, the genders $(p>0,05)$ and the genders within the grades $(p>0,05)$. Most learners in Grade 4 and Grade 7 also indicated the above reasons for their soft drink consumption $(38,2 \%$ and $38,5 \%$ respectively for the favourite beverage and $26,3 \%$ and $29,7 \%$ respectively for the taste) ( $p>$
$0,05)$. A nearly equal number of boys and girls also indicated the reasons as it being their favourite beverage $(39,2 \%$ and $37,5 \%$ respectively) along with the taste $(29,1 \%$ and $27,3 \%$ respectively) ( $>0,05)$. Most boys and girls in Grade 4 and in Grade 7 also indicated these reasons (as the favourite beverage, boys $42,1 \%$ and girls $34,2 \%$ in Grade 4 and boys $36.6 \%$ and girls $40 \%$ in Grade 7 and the taste, boys $28.9 \%$ and girls $23.7 \%$ in Grade 4 and boys $29.3 \%$ and girls $30 \%$ in Grade 7 ) ( $p>0,05)$. Grimm et al (2004) reported that children with a strong taste preference for soft drinks consume it up to five or more times per week than those with a lower taste preference for soft drinks.

Sixteen per cent $(16,2 \%)$ of the learners indicated that they consumed the beverages their parents bought as the reason for their soft drink consumption (Table 6). Grimm et al (2004) indicated that children whose parents consumed soft drinks regularly were almost three times more likely to consume soft drinks more often than five times per week, compared to those whose parents consumed little or no soft drinks. Price and peers did not seem to be important determining

TABLE 6: REASONS FOR SOFT DRINKS CONSUMED BY THE LEARNERS

\begin{tabular}{|c|c|c|c|c|c|c|c|c|c|c|c|c|c|c|c|c|c|c|}
\hline \multirow{4}{*}{ Reason $^{a}$} & \multirow{3}{*}{\multicolumn{2}{|c|}{$\begin{array}{c}\text { Total } \\
\text { respondent } \\
\text { group }(\mathrm{n}= \\
167)\end{array}$}} & \multicolumn{4}{|c|}{ Grade } & \multicolumn{4}{|c|}{ Gender } & \multicolumn{8}{|c|}{ Gender within grades } \\
\hline & & & \multirow{2}{*}{\multicolumn{2}{|c|}{$\begin{array}{l}\text { Grade } 4^{b} \\
(n=76)\end{array}$}} & \multirow{2}{*}{\multicolumn{2}{|c|}{$\begin{array}{l}\text { Grade } 7^{\mathrm{b}} \\
(\mathrm{n}=91)\end{array}$}} & \multirow{2}{*}{\multicolumn{2}{|c|}{$\begin{array}{l}\text { All boysc } \\
(n=79)\end{array}$}} & \multirow{2}{*}{\multicolumn{2}{|c|}{$\begin{array}{l}\text { All girlsc } \\
(n=88)\end{array}$}} & \multicolumn{4}{|c|}{ Grade 4} & \multicolumn{4}{|c|}{ Grade 7} \\
\hline & & & & & & & & & & & \multicolumn{2}{|c|}{$\begin{array}{l}\text { Boys }^{d} \\
(n=38)\end{array}$} & \multicolumn{2}{|c|}{$\begin{array}{l}\text { Girls }^{d} \\
(n=38)\end{array}$} & \multicolumn{2}{|c|}{$\begin{array}{l}\text { Boys }^{d} \\
(n=41)\end{array}$} & \multicolumn{2}{|c|}{$\begin{array}{c}\text { Girls }^{d} \\
(n=50)\end{array}$} \\
\hline & $\%$ & $n$ & $\%$ & $n$ & $\%$ & $\mathrm{n}$ & $\%$ & $\mathrm{n}$ & $\%$ & $\mathrm{n}$ & $\%$ & $\mathrm{n}$ & $\%$ & $\mathrm{n}$ & $\%$ & $\mathrm{n}$ & $\%$ & $n$ \\
\hline Tastes nice & 28,1 & 47 & 26,3 & 20 & 29,7 & 27 & 29,1 & 23 & 27,3 & 24 & 28,9 & 11 & 23,7 & 9 & 29,3 & 12 & 30,0 & 15 \\
\hline Looks nice & 0 & 0 & 0 & 0 & 0 & 0 & 0 & 0 & 0 & 0 & 0 & 0 & 0 & 0 & 0 & 0 & 0 & 0 \\
\hline Friends like it & 0,6 & 1 & 1,3 & 1 & 0 & 0 & 1,3 & 1 & 0 & 0 & 2,6 & 1 & 0 & 0 & 0 & 0 & 0 & 0 \\
\hline \begin{tabular}{|lll}
$\begin{array}{l}\text { Cheaper than other } \\
\text { drinks }\end{array}$ & \\
\end{tabular} & 0,6 & 1 & 1,3 & 1 & 0 & 0 & 0 & 0 & 1,1 & 1 & 0 & 0 & 2,6 & 1 & 0 & 0 & 0 & 0 \\
\hline $\begin{array}{l}\text { Healthier than other } \\
\text { drinks }\end{array}$ & 13,8 & 23 & 15,8 & 12 & 12,1 & 11 & 10,1 & 8 & 17,0 & 15 & 10,5 & 4 & 21,1 & 8 & 9,8 & 4 & 14,0 & 7 \\
\hline What mom and dad buy & 16,2 & 27 & 13,2 & 10 & 18,7 & 17 & 17,7 & 14 & 14,8 & 13 & 13,2 & 5 & 13,2 & 5 & 22,0 & 9 & 16,0 & 8 \\
\hline My favourite & 38,3 & 64 & 38,2 & 29 & 38,5 & 35 & 39,2 & 31 & 37,5 & 33 & 42,1 & 16 & 34,2 & 13 & 36,6 & 15 & 40,0 & 20 \\
\hline Did not know & 2,4 & 4 & 3,9 & 3 & 1,1 & 1 & 2,5 & 2 & 2,3 & 2 & 2,6 & 1 & 5,3 & 2 & 2,4 & 1 & 0 & 0 \\
\hline
\end{tabular}

ab,ac,ad No significant association/difference $(p>0,05)$ between variables as the reasons for soft drink consumption $(a)$ and the grades (b); the genders (c); the genders within the grades (d) 


\section{TABLE 7: SOFT DRINK INDICATIONS AS MOST POPULAR BEVERAGE BY THE LEARNERS}

\begin{tabular}{|c|c|c|c|c|c|c|c|c|c|c|c|c|c|c|c|c|c|c|}
\hline \multirow{4}{*}{$\begin{array}{l}\text { Soft drink } \\
\text { consumption }\end{array}$} & \multirow{3}{*}{\multicolumn{2}{|c|}{$\begin{array}{l}\text { Total } \\
\text { respondent } \\
\text { group } \\
(n=167)\end{array}$}} & \multicolumn{4}{|c|}{ Grade } & \multicolumn{4}{|c|}{ Gender } & \multicolumn{8}{|c|}{ Gender within grades } \\
\hline & & & \multirow{2}{*}{\multicolumn{2}{|c|}{$\begin{array}{l}\text { Grade } 4 \\
(n=76)\end{array}$}} & \multirow{2}{*}{\multicolumn{2}{|c|}{$\begin{array}{l}\text { Grade } 7 \\
(n=91)\end{array}$}} & \multirow{2}{*}{\multicolumn{2}{|c|}{$\begin{array}{l}\text { All boys } \\
(n=79)\end{array}$}} & \multirow{2}{*}{\multicolumn{2}{|c|}{$\begin{array}{l}\text { All girls } \\
(n=88)\end{array}$}} & \multicolumn{4}{|c|}{ Grade 4} & \multicolumn{4}{|c|}{ Grade 7} \\
\hline & & & & & & & & & & & $\begin{array}{l}\text { Bo } \\
(n=\end{array}$ & & $\begin{array}{l}\text { Gir } \\
(n=\end{array}$ & & $(n=$ & & $(n=$ & \\
\hline & $\%$ & $n$ & $\%$ & $n$ & $\%$ & $\mathrm{n}$ & $\%$ & $\mathrm{n}$ & $\%$ & $\mathrm{n}$ & $\%$ & $\mathrm{n}$ & $\%$ & $\mathrm{n}$ & $\%$ & $n$ & $\%$ & $n$ \\
\hline $\begin{array}{l}\text { Beverage cosnumed } \\
\text { most often }\end{array}$ & 63,5 & 106 & 48,7 & 37 & 75,8 & 69 & 67,1 & 53 & 60,2 & 53 & 57,9 & 22 & 39,5 & 15 & 75,6 & 31 & 76,0 & 38 \\
\hline Favourite beverage & 67,1 & 112 & 53,9 & 41 & 78,0 & 71 & 70,9 & 56 & 63,6 & 56 & 60,5 & 23 & 47,4 & 18 & 80,5 & 33 & 76,0 & 38 \\
\hline $\begin{array}{l}\begin{array}{l}\text { Favourite beverage } \\
\text { bought at tuck shop }\end{array} \\
\end{array}$ & 1,1 & 107 & 64,5 & 49 & 63,7 & 58 & 64,6 & 51 & 63,6 & 56 & 60,5 & 23 & 68,4 & 26 & 68,3 & 28 & 60,0 & 30 \\
\hline \begin{tabular}{|l|} 
Favourite beverage \\
consumed at restau- \\
rants with take aways
\end{tabular} & 64,7 & 108 & 59,2 & 45 & 69,2 & 63 & 68,4 & 54 & 61,4 & 54 & 71,1 & 27 & 47,4 & 18 & 65,9 & 27 & 72,0 & 36 \\
\hline
\end{tabular}

a Asked in comparison to other beverages (i.e. cold drinks, fruit juices, water including bottled and flavoured water, milk, milkshakes, flavoured milk and yoghurt drinks) in separate questions

factors, as only one learner respectively indicated that he/she buys it because it is cheaper than other beverages and because his/her peers liked it. Some learners $(13,8 \%)$ also indicated they consumed soft drinks because it is healthier than other beverages (Table $6)$.

\section{Soft drinks as most popular learner beverage}

Approximately $64 \%(63,5 \%)$ of the learner group indicated that they consumed soft drinks more often than the other beverages in the multiple-choice listing (Table 7). These included cold drinks, fruit juices, water (including bottled and flavoured), milk, milkshakes, flavoured milk and yoghurt drinks. Cold drinks were the beverage indicated next to be consumed most often $(16,2 \%)$. Only two learners indicated that they consumed milk most often. Although both grades indicated that they consumed soft drinks most often, more of the learners in Grade $7(75,8 \%)$ indicated it than of the learners in Grade $4(48,7 \%)$. Slightly more of the boys $(67,1 \%)$ indicated that they consumed soft drinks most often than of the girls $(60,2 \%)$. In Grade 4 , soft drinks were also consumed more often by more of the boys than of the girls (57,9\% and $39,5 \%$ respectively). In Grade 7 , threequarters of the boys $(75,6 \%)$ and the girls $(76 \%)$ drank soft drinks most often.

When asked about the respondent group's favourite beverage among those listed, $67,1 \%$ selected soft drinks (Table 7). This was also the reason provided by the group for soft drinks being the beverage mostly commonly consumed. Fruit juices $(7,8 \%)$ followed soft drinks as the indicated next favourite beverage. Only three learners indicated that milk was their next favourite beverage. In both grades, soft drinks were the favourite beverage, but it was indicated by more of the learners in Grade $7(78 \%)$ to be the favourite beverage than of the learners in Grade $4(53.9 \%)$. More of the boys $(70,9 \%)$ indicated that soft drinks were their favourite beverage compared to the girls $(63,6 \%)$. In Grade 7 , more than three-quarters of the boys and girls $(80,5 \%$ and $76 \%$ respectively) indicated that soft drinks were their favourite beverage, whereas it was less favoured in Grade 4, with only
$60,5 \%$ of the boys and $47,4 \%$ of the girls that indicated this (Table 7).

Soft drinks were the beverage indicated from those listed to be bought mostly at the tuck shop among the respondents $(64,1 \%)$ and the two grade groups (Grade 4 64,5\% and Grade 7 63,7\%). Cold drinks $(5,4 \%)$ were the beverage next indicated to be bought mostly. An equal percentage of the boys and the girls $(64,6 \%$ and $63,6 \%$ respectively) indicated that soft drinks were the favourite beverage to buy at the tuck shop. In both grades, a nearly equal percentage of the boys and the girls bought soft drinks at the tuck shop (in Grade $460,5 \%$ of the boys and $68,4 \%$ of the girls and in Grade $768,3 \%$ of the boys and $60 \%$ of the girls) (Table 7).

Most $(64,7 \%)$ of the learners chose soft drinks from the listed beverages as beverage when dining out or with take-aways (Table 7) which was followed by milkshakes $(20,4 \%)$ as choice. French et al (2003) investigated the trends between 1977/1978 and $1994 / 1998$ in the prevalence, amounts and sources of soft drink consumption of six- to seventeen-year olds. The results indicated that children mostly consumed soft drinks at home, but also obtained it from fast food and other restaurants (53\%), vending machines $(48 \%)$ and other sources (37\%). Both grade groups (59,2\% in Grade 4 and 69,2\% in Grade 7 ) indicated soft drinks as their favourite beverage consumed when dining out or with take-aways. A higher percentage of the boys $(68,4 \%)$ than the girls $(61,4 \%)$ indicated soft drinks as the preferred beverage choice when dining out or with take-aways. In Grade 4, far more of the boys $(71,1 \%)$ than of the girls $(47,4 \%)$ indicated this. However, in Grade 7, more of the girls $(72 \%)$ indicated this than of the boys $(65,9 \%)$ (Table 7).

\section{Marketing impact of soft drinks on the learners}

Eighty percent $(79.6 \%)$ of the learners were influenced in their choice of soft drink by marketing on television (Table 8). Marketing did not impact the soft drink consumption significantly different between the grades $(p>0,05)$, the genders $(p>0,05)$ or the gen- 


\section{TABLE 8: ADVERTISING INFLUENCE ON SOFT DRINK BUYING BY THE LEARNERS}

\begin{tabular}{|c|c|c|c|c|c|c|c|c|c|c|c|c|c|c|c|c|c|c|}
\hline \multirow{4}{*}{$\begin{array}{l}\text { Advertising } \\
\text { influence }^{\mathrm{a}}\end{array}$} & \multirow{3}{*}{\multicolumn{2}{|c|}{$\begin{array}{l}\text { Total respon- } \\
\text { dent group } \\
(n=167)\end{array}$}} & \multicolumn{4}{|c|}{ Grade } & \multicolumn{4}{|c|}{ Gender } & \multicolumn{8}{|c|}{ Gender within grades } \\
\hline & & & \multirow{2}{*}{\multicolumn{2}{|c|}{$\begin{array}{c}\text { Grade } 4^{b} \\
(n=76)\end{array}$}} & \multirow{2}{*}{\multicolumn{2}{|c|}{$\begin{array}{c}\text { Grade } 7 \mathrm{~b} \\
(\mathrm{n}=91)\end{array}$}} & \multirow{2}{*}{\multicolumn{2}{|c|}{$\begin{array}{c}\text { All boysc } \\
(n=79)\end{array}$}} & \multirow{2}{*}{\multicolumn{2}{|c|}{$\begin{array}{c}\text { All } \\
\text { girlsc } \\
(n=88)\end{array}$}} & \multicolumn{4}{|c|}{ Grade 4} & \multicolumn{4}{|c|}{ Grade 7} \\
\hline & & & & & & & & & & & \multicolumn{2}{|c|}{$\begin{array}{l}\text { Boys }^{d} \\
(n=38)\end{array}$} & \multicolumn{2}{|c|}{$\begin{array}{c}\text { Girlsd }^{d} \\
(n=38)\end{array}$} & \multicolumn{2}{|c|}{$\begin{array}{l}\text { Boys }^{d} \\
(n=41)\end{array}$} & \multicolumn{2}{|c|}{$\begin{array}{c}\text { Girls }^{d} \\
(n=50)\end{array}$} \\
\hline & $\%$ & $n$ & $\%$ & $\mathrm{n}$ & $\%$ & $n$ & $\%$ & $\mathrm{n}$ & $\%$ & $n$ & $\%$ & $n$ & $\%$ & $\mathrm{n}$ & $\%$ & $\mathrm{n}$ & $\%$ & $n$ \\
\hline Yes & 79,6 & 133 & 84,2 & 64 & 75,8 & 69 & 75,9 & 60 & 83,0 & 73 & 81,6 & 31 & 86,8 & 33 & 70,7 & 29 & 80,0 & 40 \\
\hline No & 20,4 & 34 & 15,8 & 12 & 24,2 & 22 & 24,1 & 19 & 17,0 & 15 & 18,4 & 7 & 13,2 & 5 & 29,3 & 12 & 20,0 & 10 \\
\hline
\end{tabular}

ab,ac,ad No significant association/difference $(p>0,05)$ between variables as the advertising influence on soft drink buying (a) and the grades (b); the genders (c); the genders within the grades (d)

ders within the grades $(p>0,05)$. In both grade groups and genders, most learners indicated being influenced by soft drink advertisements on television (Grade $484,2 \%$ and Grade $775,8 \%$ and the girls $83 \%$ and the boys $75.9 \%$ ) ( $p>0,05$ for each). Most boys and girls in Grade $4(81,6 \%$ and $86,8 \%$ respectively) and Grade 7 (70,7\% and $80 \%$ respectively) also indicated that soft drink advertisements usually influenced their purchases $(p>0,05)$. In a study that examined the exposure of Bulgarian children to television food advertising and that made a content analysis of the food/beverage advertisements during children's television programmes, the following was concluded: $33,4 \%$ of all advertisements were food/ beverage related, $57 \%$ targeted children, and the most advertised products were salty/sweetened snacks and cereals, sweets, soft drinks and salty foods (Galcheva et al, 2008). Clearly children are exposed to the advertising of unhealthy food choices, including soft drinks.

\section{CONCLUSIONS}

Besides determining that most of the participating learners consumed soft drinks, it was determined that the usual amount consumed per day exceeded that reported by Cullen et al (2002), which examined, among other beverages, the consumption of soft drinks among middle-class schoolchildren in the same age group as this study. The small number of non-consumers in this study and the fact that the data were based on usual consumption, and not specifically consumption over the previous few days, could be the reasons why the average consumption in this study was higher than in the abovementioned study. The average amount of soft drinks consumed by the Wynberg learners was similar to that found being consumed by 13- to 18-year-old American children when the non-consumers were also excluded from this group (Jacobson, 2005:2). The usual consumption of one or two soft drinks in a large volume per day by the majority of the learners was responsible for the large amount of soft drinks consumed. The convenience of the $500 \mathrm{ml}$ bottle could be a reason for the learners consuming this size.

Soft drinks as the favourite beverage and its taste were powerful factors conducive to soft drink consumption in this learner group. The learners also indicated the reason for their soft drink consumption as what their parents buy. This indicated the availability of soft drinks in the household. These influences were equally important for both grades, both genders and the genders within the grades. A further factor conducive to the high soft drink consumption could be the lower education level of the parents, a factor identified by Cullen et al (2002). The level of education of most adults (aged 20 and older) residing in the Wynberg area is grades 8 to $11(31,79 \%)$ and Grade 12 $(31,55 \%)$ (Strategic Development Information and GIS, 2001). Soft drink availability at tuck shops in schools also contributed to the high soft drink consumption within this learner group, as learners rather purchased soft drinks than they did other beverages at the school tuck shops. The environment outside the school with reference to television viewing, advertising and eating out was also supportive of their soft drink consumption. This was equally important for both the grades, both genders and both genders within the grade groups. The soft drink price and the influence of peers were not predictive factors for soft drink consumption in this study.

Grade 7 learners did not consume larger amounts of soft drinks than the Grade 4 learners. The popularity of soft drinks increased with the grade groups. Soft drinks were more popular among Grade 7 than Grade 4 learners, because more learners consumed soft drinks most often in Grade 7 and were also the favourite beverage of most Grade 7 learners. Older age as a predictor of children's soft drink consumption, as obtained from studies done elsewhere, was also supported by this study.

In both grades the usual daily amount and number of servings of soft drinks consumed by the boys were somewhat more than that consumed by the girls. Although most boys and girls in grades 4 and 7 consumed one or two servings, a larger percentage of boys than girls in Grade 4 and Grade 7 consumed more than three soft drink servings per day. In both grades, most boys and girls consumed the larger serving sizes. More girls than boys consumed the smaller serving size, but significantly more so for the boys in Grade 4 and the girls in Grade 7 compared to Grade 4. Soft drinks were more popular among boys than girls in the younger age group (Grade 4) as more boys than girls indicated it to be the beverage drank most often, it being their favourite beverage, also when eating out and with take-aways, while in Grade 7 it was of almost equal popularity between the two genders.

This study supported the major factors predictive of 
soft drink consumption as reported elsewhere. Taste, advertising, universal availability, low price and current school practices regarding soft drink availability are all factors that have made soft drinks a popular beverage among children. These beverages are therefore no longer considered as an occasional treat but as part of children's daily diet (Jacobson, 2005:25).

The high consumption of soft drinks among the learners (mostly coloured children) seen in this study may assumingly be partly the reason for the high prevalence of dental caries among these children. In the twelve-year-old age group in the South African population, coloured children have the highest dental caries prevalence (Ayo-Yusuf et al, 2007).

The limitations of this study were the self-report of the beverage intakes and the limited generalisability of the sample. The children in this study were aged nine years and older. The self-reported dietary consumption may therefore not be a major limitation. However, the high percentage of the learners indicating to be soft drink consumers together with the calculated usual daily amount of soft drinks consumed across the learner groups being larger than that found in some other studies may be questioned - in particular with regard to purchase cost involved. The less expensive brands indicated by the learners to be the soft drinks consumed and the numerous factors identified that support soft drink consumption, may not fully explain the high consumption found.

\section{RECOMMENDATIONS}

Grade 4 and Grade 7 learners may need to improve their beverage choices in order to improve their overall nutrition and health if the high soft drink consumption found in this study is a common occurrence. Soft drinks should only be consumed on special occasions and not as a usual habit. Other beverages that should replace soft drinks in the diet to maintain good health are milk, fruit juices and water. Ideally, fluid needs should predominantly be provided by calorie-free beverages (Popkin et al, 2006), which may include diet or unsweetened carbonated beverages. These beverages accounted for approximately $4 \%$ of the total carbonated beverages consumed by US children aged six to seventeen in 1994/1998 (French et al, 2003) and can be recommended for children to decrease their energy consumption through soft drinks. The consumption of these beverages were not encountered in this learner group.

A number of recommendations can be made to reinforce healthy nutritional beverage habits among learners. These are:

- Home environment: Parents should serve as role models to their children to promote healthier beverage choices and as a result limit their soft drink consumption and availability in the household.

- School environment: Learners should be taught at school from an early age about basic nutrition, including healthier beverage choices in order to help and develop healthy eating patterns. Some learners perceived soft drinks to be healthier than other drinks, especially the younger grades. Guidance in this regard should be provided at home and at school. School tuck shops should limit selling soft drinks to selected days of the week and at special events. This will force children to buy other beverages, such as yoghurt drinks, flavoured milk and fruit juices. Diet or unsweetened (carbonated) beverages should also be introduced to their beverage range.

- Environment outside the school: Dairy companies should advertise their products during children television programmes in such a way that children would be eager to buy them. Dairy companies together with health authorities should also embark on educating parents (and their children) on the benefits of consuming milk and milk products.

No studies were found on the soft drink consumption of South African children and their reasons for the consumption, which only made comparisons in this regard to studies done elsewhere possible. Similar studies to investigate the soft drink consumption of South African children should be done to obtain a more comprehensive overview to confirm this dietary and resulting health concern among South African children. Such studies should possibly employ a multiple-administration design to address the limitations of this investigation. Nonetheless, the study provides evidence for addressing the beverage choices of South African children as an essential education topic in the primary school-based healthy lifestyle intervention (Healthkick) in the Western Cape (Sauls et al, 2008).

\section{REFERENCES}

AYO-YUSUF, OA, AYO-YUSUF, IA \& VAN WYK, PJ. 2007. Socio-economic inequities in dental caries experience of 12-year-old South Africans: policy implications for prevention. Journal of the South African Dental Association 62(1):6-11.

BALLEW, C, KEUSTER, S \& GILLESPIE, C. 2000 Beverages choices affect adequacy of children's nutrient intakes. Archives of Pediatrics and Adolescent Medicine 154:1148-1152.

BOWMAN, S. 2002. Beverage choices of young females: changes and impact of nutrient intakes. Journal of the American Dietetic Association 102:12341236.

CULLEN, KW, ASH, DM \& WARNEKE, C. 2002. Intake of soft drinks, fruit-flavoured beverages, and fruits and vegetables by children in grades 4 through 6. American Journal of Public Health 92 (9):14751478.

FERNANDES, MM. 2008. The effect of soft drink availability in elementary schools on consumption. Journal of the American Dietetic Association 108:1445-1452.

FORESHEE, RA \& STOREY, ML. 2003. Total beverage consumption and beverage choices among children and adolescents. International Journal of Food Sciences and Nutrition 54(4):297-307. 
FRENCH, SA, LIN, B \& GUTHRIE, JF. 2003. National trends in soft drink consumption among children and adolescents age 6 to 17 years: prevalence, amounts, and sources, $1977 / 1978$ to $1994 / 1998$. Journal of the American Dietetic Association 103:1326-1331.

FRIED, EJ \& NESTLE, M. 2002. The growing political movement against soft drinks in schools. Journal of the American Medical Association 228(17):2181.

GALCHEVA, SV, IOTAVA, VM \& STRATEV, VK. 2008. Television food advertising directed towards Bulgarian children. Archives of Disease in Childhood 93:857-861.

GIAMMATTEI, J, BLIX, G \& MARSHAK, HH. 2003. Television watching and soft drink consumption: Association with obesity in 11- to 13-year old schoolchildren. Archives of Pediatrics and Adolescent Medicine 157:882-886.

GRIMM, GC, HARNACK, L \& STORY, M. 2004. Factors associated with soft drink consumption in schoolaged children. Journal of the American Dietetic Association 104:1244-1249.

HARNACK, L, STANG, J \& STORY, M. 1999. Soft drink consumption among US children and adolescents: nutritional consequences. Journal of the American Dietetic Association 99:436-441.

JACOBSON, MF. 2005. Soft drinks are harming American's health. $2^{\text {nd }}$ ed. Washington, DC. Center for Science in the Public Interest.

JOHNSTON, LD, DELVA, J \& O'MALLEY, PM. 2007. Soft drink availability, contracts, and revenues in American secondary schools. American Journal of Preventive Medicine 33(4S):S209-S225.

LABADARIOS, D, STEYN, NP \& MAUNDER, E. 2005. The National Food Consumption Survey (NFCS): South Africa, 1999. Public Health Nutrition 8 (5):533-543.

LANGENHOVEN, ML, CONRADIE, PJ \& WOLMARANS, P. 1991. Food Quantities Manual. 2nd ed. South Africa: Medical Research Council, National Research Programme for Nutritional Intervention. LIVINGSTONE, MBE, \& ROBSON, PJ. 2000. Measurement of dietary intake in children. Proceedings of the Nutrition Society 59:279-293.

MAHMOUD, TJ. 2009. Carbonated beverages and urinary excretion. Middle East Journal of Family Medicine 7(5):8-12.

NEL, JH \& STEYN, NP. 2002. Report on South African food consumption studies undertaken amongst different population groups (1983-2000): average intakes of foods most commonly consumed. Pretoria. Department of Health.

NESTLE, M. 2000. Soft drink 'pouring rights': marketing empty calories. Public Health Reports 115:308319.

NEUMAN, WL. 2006. Social research methods. $6^{\text {th }}$ ed. Boston, MA. Pearson Education.

OVERBY, NC, LILLEGAARD, ITL \& JOHANSSON, L. 2003. High intakes of added sugar among Norwegian children and adolescents. Public Health Nutrition 7
(2):285-293.

PARMENTER, K \& WARDLE, J. 2000. Evaluation and design of nutrition knowledge measures. Journal of Nutrition Education 32(5):269-277.

POPKIN, BM, ARMSTRONG, LE \& BRAY, GM. 2006. A new proposed guidance system for beverage consumption in the United States. American Journal of Clinical Nutrition 85:960-966.

RAMPERSAUD, GC, BAILEY, LB \& KAUWELL, GPA. 2003. National survey beverage consumption data for children and adolescents indicate the need to encourage a shift toward more nutritive beverages. Journal of the American Dietetic Association 103:97-100.

SAULS, L, DE VILLIERS, A \& FOURIE, J. 2008. The nutrition environment in primary schools in the Western Cape (Healthkick Project). South African Journal of Clinical Nutrition 21(3)(Suppl):182 (Abstract).

STATISTICS SOUTH AFRICA. 2005/2006. Income and expenditure of households: Statistical Release P0100. Pretoria. Statistics South Africa.

STATSOFT INC. 2005. STATISTICA (Data analysis software system), version 7.1. http:// www.statsoft.com.

STEYN, NP, MAUNDER, EMW \& LABADARIOS, D. 2006. Foods and beverages that make significant contributions to macro- and micronutrient intakes of children in South Africa - do they meet the foodbased dietary guidelines? South African Journal of Clinical Nutrition 19(2):66-76.

STEYN, NP, MYBURGH, NG \& NEL, JH. 2002. Evidence to support a food-based dietary guideline on sugar consumption in South Africa. Bulletin of the World Health Organization 81:599-608.

STRUWIG, FW \& STEAD, GB. 2001 Planning, designing and reporting research. Cape Town. Pearson Education.

ST-ONGE, M, KELLER, KL \& HEYMSFIELD, SB. 2003. Changes in childhood food consumption patterns: a cause for concern in light of increasing body weights. American Journal of Clinical Nutrition 78:1068-1073.

STOREY, ML, FORESHEE, RA \& ANDERSON, PA. 2004. Associations of adequate intake of calcium with diet, beverage consumption, and demographic characteristics among children and adolescents. Journal of the American College of Nutrition 23(1):18-33.

Strategic Development Information and GIS from 2001 Census data. 2001. City of Cape Town - Census 2001 - Wynberg. Demographic profile, employment profile, housing profile, service profile. Available on line. URL: http://www.capetown.gov.za. Accessed 17 February 2009.

VAN WYK, P \& VAN WYK, C. 2004. Oral health in South Africa. International Dental Journal 54:373377.

WHITNEY, EN \& ROLFES, SR. 1996. Understanding nutrition. $7^{\text {th }}$ ed. Minneapolis, St Paul. West Publishing Company. 